University of Nebraska - Lincoln

DigitalCommons@University of Nebraska - Lincoln

Journal for the Advancement of Developing Institute for the Advancement of Developing Economies

Economies

2019

Credit Constraints and Agricultural Productivity of Rural

Households in Nigeria

Olugbenga K. Omolade

Abimbola O. Adepoju

Follow this and additional works at: https://digitalcommons.unl.edu/jade

Part of the Econometrics Commons, Growth and Development Commons, International Economics Commons, Political Economy Commons, Public Economics Commons, and the Regional Economics Commons

This Article is brought to you for free and open access by the Institute for the Advancement of Developing Economies at DigitalCommons@University of Nebraska - Lincoln. It has been accepted for inclusion in Journal for the Advancement of Developing Economies by an authorized administrator of DigitalCommons@University of Nebraska - Lincoln. 


\title{
Credit Constraints and Agricultural Productivity of Rural Households in Nigeria
}

\author{
Olugbenga K. Omolade, Abimbola O. Adepoju* \\ Department of Agricultural Economics, University of Ibadan, Nigeria
}

\begin{abstract}
This study, employing descriptive statistics and the Endogenous Switching Model, examined the link between credit constrained condition and agricultural productivity of rural households in Nigeria. Findings show that under credit constrained condition, education, labour, technology and other production inputs were not optimally utilized by the households. Credit constrained households had lower productivity than a random household from the sample would have had. However, in credit constrained households, being a male-headed household implied higher productivity. On the other hand, high value of assets and cost of hired labour had negative effects on productivity, while level of education and access to information had no significant effects. The study thus recommended intensification of efforts at ensuring the formulation of rural credit policies that will provide access to a reasonable amount of credit to rural households to secure required farm inputs, while formal credit institutions should diversify their loan scheme to incorporate different financial needs of the households.
\end{abstract}

Keywords: Africa, agriculture, credit facility, endogenous switching model. *Corresponding author: abimbola.adepoju@yahoo.com / +234 8033335958

\section{INTRODUCTION}

Agriculture in the pre-historic period sustained humanity over the years with little or no significant attachment to capital for production (Oladeebo \& Oladeebo, 2008). However, in present day, capital is regarded as one of the major needs in expanding production and modernizing agriculture (Udoh, 2005). In other words, modernizing agriculture requires large infusion of credit to finance inputs (Ololade \& Olagunju, 2013). Also, the significance of mechanization and improved farming activities to enhance food sufficiency for the teeming population as well as the transformation of the economy into perhaps an industrialized one (in line with agriculture-based economic development strategy), has prioritized the need for credit (Ekpebu, 2006). In this regard, the provision of credit can be a powerful economic force for development if used to procure agricultural inputs that are not otherwise available to farmers from their own financial resources. For instance, Brazil through its agricultural financial incentives to its farmers was able to change its hitherto underdeveloped status to that of a newly industrialized country (Platteau, 2008).

In most developing countries, agricultural production is undertaken by small-scale farmers most of whose labour force, management, and capital originate from the household (World Bank, 2008). Access to improved agricultural technologies is often expensive and cannot be self-financed (Obisesan, 2013). In other words, the use of agricultural technologies and consequently 
agricultural productivity is low as a result of the lack of access to credit facilities (Phillip, Nkoya $\&$ Oni, 2009). For instance, credit constraints affect farm production directly and indirectly. While the former affects the purchasing power of producers to procure farm implements and make farmrelated investments which they can fall back on to help them overcome credit constraints, the latter affects the risk behavior of producers (Guirkinger \& Boucher, 2005). This implies that a creditconstrained farmer will invest in less risky and less productive technologies rather than in the more risky but productive ones (Dercon \& Christaensen, 2011).

In Nigeria, government over the years has prioritized the agricultural sector in its expenditure policies; establishing numerous agricultural credit institutions that could facilitate the flow of credit to farmers as well as appealing to the financial institutions to devote a certain percentage of their loanable funds to farmers while ensuring a favourable long tenure and single digit lending rate (Olajide \& Aderolu, 2017). Although, agricultural credit responded positively, particularly in the early 80 's, it has since then been faced with several challenges arising from its source, availability, and use. Thus, there is poor financial projection and planning, high level of illiteracy among farmers and lack of required information as to how, when and where to obtain credit. In addition, there is lack of formal national credit policy and paucity of credit institutions which can assist farmers (Olagunju \& Adeyemo, 2008).

Further, non-institutional creditors accounts for $70 \%$ of the total credits received by Nigerian farming population (Oboh, 2011), because the institutional lending system has failed to meet the objectives for which they were set up which include to serve the rural poor and be sustainable credit institutions. Consequently, the limited availability of such required credit services has undermined agricultural activities of innovative and sustainable smallholder farmers.

This study contributes to empirical literature on the link between credit constraints and productivity of farming households in Nigeria. In analysing the implications of being credit constrained or unconstrained on agricultural productivity, econometrically, the problems of unobserved heterogeneity and possible endogeneity could arise. These issues if not accounted for could lead to ambiguous policy inferences. Most comparable studies (Abu, Odoemenem \& Ocholi, 2011; Ugbajah, 2011) have used methodologies that have ignored these issues. A key contribution of this study is that it controls for selection bias by estimating an endogenous switching regression model employing a nationally representative dataset; most comparable studies rely on regional data. Findings from this study will therefore assist policymakers in prescribing policies on sustainable institutional arrangement for provision of rural credit to constrained households for improved productivity and ultimately a total transformation of the agricultural sector. Thus, this study is aimed at examining the link between credit constraints and agricultural productivity by (i) identifying the sources of credit available to rural households and (ii) examining the effect of credit constraints on the productivity of farming households in rural Nigeria.

\section{MATERIALS AND METHODS}

Data from the second wave of the General Household Survey-Panel (GHS-Panel) conducted in 2012/13 by the Nigeria National Bureau of Statistics and supported by the World Bank, National Food Reserve Agency (NFRA), the Bill and Melinda Gates Foundation (BMGF) and the Federal Ministry of Agriculture and Rural Development (FMA\&RD) was used. The sample design was a 
2-stage stratified sampling. The first stage involved the selection of Enumeration Areas (EAs) based on probability proportional to size (PPS) of the total EAs in each state and the Federal Capital Territory and the total households listed in those EAs. A total of 500 EAs were selected using this method. The survey is representative at the national, zonal and rural/urban levels with the total sample size of 5,000 households consisting of 3370 rural households and 1630 urban households. The final number of agricultural or rural households interviewed was 2431 . However, owing to missing information relevant for this study, only 655 agricultural households constituted the sample size.

Descriptive and econometric tools were the analytical tools employed in the analysis of data. While, descriptive statistics such as mean, frequency distribution and percentages were used in describing the various socio-economic characteristics of farming households and that of their credit sources, an endogenous switching regression model was used to analyze the factors influencing the credit constrained condition of rural households and the effect of credit constrained condition on their productivity.

\subsection{Endogenous Switching Regression Model}

In estimating the effect of being credit constrained on productivity, there are two issues. The first is the heterogeneity between credit-constrained and unconstrained households (Fengxia, Jing \& Allen, 2010), as all credit constrained and unconstrained households are not homogenous with respect to their credit demand (Feder, Lau, Lin \& Luo, 1990). In addition, the effect on agricultural productivity may not be independent of credit status, since factors of production may have differential effects on agricultural productivity under credit constrained condition than is the case under unconstrained conditions. Therefore, estimation methods that pool all sampled observations to estimate production/output functions with credit as an input or a determinant may not be appropriate. As a result, separate functions for credit-constrained and unconstrained households were examined (Ayalew, Klaus \& Marguerite, 2014).

The second issue is endogeneity. Households that are unconstrained can separate consumption decisions from farm production decisions and choose production inputs that is most suitable for the production process (Foltz, 2004). In contrast, credit-constrained households may deviate from input-optimal levels to allocate limited available resources between consumption and production and thus, may have lower productivity. However, being credit constrained and having low productivity could also be caused by a common unobserved shock such as illness of the farmer. Therefore, possible sample selection bias may arise and it is important to account for this sample bias. Thus, the econometric problem involves both heterogeneity and sample selection. This motivates the use of an endogenous switching regression model (Maddala, 1983), which consists of a joint estimation of the probability of being credit constrained and the productivity level. An endogenous switching regression model is estimated following Lokshin and Sajaia (2004) to test the likelihood of being credit constrained as well as the relationship between credit constraints and agricultural productivity.

\subsection{Model Specification and Estimation Procedure}


The first stage of the switching regression model was the application of a probit model to determine those factors influencing a farm household's credit condition considering a number of socioeconomic and credit variables. The credit condition of the $i^{\text {th }}$ household is described by a credit demand function, $I^{*}$, that is, a function of a vector of explanatory variables (such as a number of socio-economic and credit variables). This can be described as follows following: Lokshin and Sajaia (2004); Ayalew et al. (2014); Boucher, Guirkinger and Trivelli (2009) and Awotide, Abdoulaye, Alene and Manyong (2015).

$\mathrm{Ii}^{*}=\gamma \mathrm{Zi}+\theta^{\prime} \mathrm{Wi}+\mathrm{ui}$

Where $\mathrm{Z}$ is a vector of exogenous variables, $\gamma$ and $\theta^{\prime}$ are vector of parameters to be estimated, Wi is a vector of instrumental variables, and ui is a random disturbance. The function that indicates the household's credit status can be specified as:

$\left\{\begin{array}{l}I i=1, \text { if } \gamma Z_{i}+\theta^{\prime} W_{i}+u_{i}>0 \\ I i=0, \text { if } \gamma Z_{i}+\theta^{\prime} W_{i}+u_{i} \leq 0\end{array} \quad u \sim N(0,1)\right.$

The second stage in the switching regression model was to estimate the separate regression equations, used to model the productivity of the household, conditional on a specified credit status for the two groups (constrained and unconstrained). The production function of the two groups household is modeled by:

$\left\{\begin{array}{l}y_{1 i}=X_{1 i} \beta_{1}+\varepsilon_{1 i} \text { if } I \mathrm{i}=1 \\ y_{2 i}=X_{2 \mathrm{i}} \beta_{2}+\varepsilon_{2 i} \text { if } I \mathrm{i}=0\end{array}\right.$

where $y_{1 i}$ and $y_{2 i}$ are the productivity for credit-constrained and credit-unconstrained households, respectively; $X_{1 i}$ and $X_{2 i}$ are vectors of exogenous variables believed to influence productivity; $\beta_{i}$ and $\beta_{i}$ are vectors of parameters; and $\varepsilon_{1 i}$ and $\varepsilon_{2 i}$ are the random disturbance terms. Here, $u_{i}, \varepsilon_{1 i}$, and $\varepsilon_{2 i}$ are assumed to have a tri-variate normal distribution with mean vector zero and covariance matrix. Because the disturbance terms in equation (5) are conditional on the sample selection criterion and have non-zero expected values, the Ordinary Least Squares (OLS) estimates of $\beta_{1}$ and $\beta_{2}$ will suffer from sample selection bias and are inconsistent (Maddala, 1983). Some studies have used a two-stage estimation method to estimate the system of equations (4) and (5) following Feder et al. (1990); Freeman, Ehui and Jabbar (1998); Carter and Olinto (2003); Petrick (2005), while some have used the weighted least squares (Freeman et al., 1998), limited to situations in which the exact form of heteroskedasticity is known, which is rarely the case (Alene \& Manyong, 2007). Therefore, in order to estimate the endogenous switching regression model efficiently and with no strict assumptions, the study used the Full Information Maximum Likelihood (FIML) method following Lokshin and Sajaia (2004). Both Wooldridge (2010) and Greene (2008) characterized the FIML as generally the most efficient estimation strategy to estimate models with endogenous switching.

The dependent variable in the selection or criterion equation (equation 4) is the household's credit status (Constrained). This variable takes a value of 1 if the household is credit constrained and 0 otherwise, while the vector of instruments $\mathrm{Wi}$, include household savings, nonfarm enterprise revenue, and value of crop yield. These instrumental variables have effect on credit constrained 
status of farming households but not its crop productivity. The equation can be explicitly described as follows:

$I=$ Credit constrained condition (Constrained $=1,0$ if Otherwise)

$\mathrm{Z}_{1}=$ Age of the farmers (actual age in years)

$Z_{2}=$ Age squared (years)

$\mathrm{Z}_{3}=$ Gender of the farmer (male $=1,0$ if otherwise)

$Z_{4}=$ Marital status (married $=1,0$ if otherwise)

$Z_{5}=$ Household head had primary education only (Yes $=1,0$ Otherwise)

$\mathrm{Z}_{6}=$ Household head had secondary education only (Yes=1, 0 Otherwise)

$\mathrm{Z}_{7}=$ Household head had tertiary education only (Yes $=1,0$ Otherwise)

$Z_{8}=$ Household size (actual number)

$\mathrm{Z}_{9}=$ Primary occupation (Farming $=1,0$ if Otherwise)

$\mathrm{Z}_{10}=$ Land acquisition (Purchased $=1,0$ if Otherwise)

$\mathrm{Z}_{11}=$ Land acquisition (Inheritance $=1,0$ if Otherwise)

$\mathrm{Z}_{12}=$ Household has savings (Yes $=1,0$ if Otherwise)

$\mathrm{W}_{1}=$ Sale value of household assets (Naira)

$\mathrm{W}_{2}=$ Nonfarm enterprise revenue (Naira)

$\mathrm{W}_{3}=$ Crop yield (Naira)

The dependent variable in the outcome equation (equation 5) of the switching endogenous model is productivity $(\operatorname{Prod})$. Because farmers were engaged in different crop production and cropping system, measurement of productivity was a real challenge as different crops had different average yields under similar conditions. Hence, there was a need to find a measure that could incorporate all the production types and varying crops. According to Brauw (2014), one potential measure of productivity to use in this case would be the gross value of crops grown by the household. This measure was constructed by multiplying the unit price of the crop and the quantity of each crop harvested. Therefore, monetary values of output were used instead of quantities to measure productivity to make it comparable across households. Productivity was measured as output value divided by input cost value per household.

The explanatory variables include age, sex, education level, number of household member, sale value of household assets, use of inputs, method of land acquisition, household distance to main road and market, access to information, labour cost, and type of cropping. The variable age squared is included, as the effect of age may not be linear. The outcome equation is explicitly described as follows:

$\mathrm{Y}$

$\mathrm{X}_{1}$

$\mathrm{X}_{2}$

$\mathrm{X}_{3}$

$\mathrm{X}_{4}$

$\mathrm{X}_{5}$

$\mathrm{X}_{6}$

$\mathrm{X}_{7}$

$\mathrm{X}_{8}$
$=$ Productivity (Naira)

$=$ Age of household head (years)

$=$ Age squared (years)

$=$ Sex of household head (male $=1,0$ if otherwise)

$=$ Number of household members

$=$ Household head had primary education only ( $\mathrm{Yes}=1,0$ Otherwise)

$=$ Household head had secondary education only (Yes $=1,0$ Otherwise)

$=$ Household head had tertiary education only (Yes $=1,0$ Otherwise)

$=$ Primary occupation of household head (Farming $=1,0$ otherwise) 


$\begin{array}{ll}\mathrm{X}_{9} & =\text { Total land cultivated (hectares) } \\ \mathrm{X}_{10} & =\text { If farming household used fertilizer on farmland (Yes }=1,0 \text { Otherwise) } \\ \mathrm{X}_{11} & =\text { If farming household used pesticide on farmland (Yes }=1,0 \text { Otherwise) } \\ \mathrm{X}_{12} & =\text { If farming household used herbicide on farmland (Yes }=1,0 \text { Otherwise) } \\ \mathrm{X}_{13} & =\text { If farming household used irrigation on farmland (Yes }=1,0 \text { Otherwise) } \\ \mathrm{X}_{14} & =\text { Cost of labour (value in Naira) } \\ \mathrm{X}_{15} & =\text { Distance to market (Kilometer) } \\ \mathrm{X}_{16} & =\text { Distance to road (Kilometer) } \\ \mathrm{X}_{17} & =\text { If household practiced mixed cropping (Yes }=1,0 \text { Otherwise) } \\ \mathrm{X}_{18} & =\text { If household practiced mono cropping (Yes }=1,0 \text { Otherwise) } \\ \mathrm{X}_{19} & =\text { If household acquired farmland by purchase (Yes }=1,0 \text { Otherwise) } \\ \mathrm{X}_{20} & =\text { If household acquired farmland by inheritance (Yes=1,0 Otherwise) } \\ \mathrm{X}_{21} & =\text { If household had access to information through phone (Yes=1,0 } \\ \mathrm{X}_{22} & \\ \mathrm{Oth}_{23} & =\text { If household had access to information through radio (Yes }=1,0 \\ \mathrm{X}_{23} & \end{array}$

\section{RESULTS AND DISCUSSION}

\subsection{Socioeconomic Characteristics of Households}

Table 1 presents the distribution of households by selected socioeconomic characteristics. The distribution of respondents by sex revealed that majority $(91.6 \%)$ of the households in the study area were headed by males while female heads constituted only a minority $(8.4 \%)$. The mean age of households' head was $48.2 \pm 13.0$. Almost half of the respondents had household sizes of between 4 and 10 members, with the mean household size of approximately $7 \pm 3$ members. However, more than half $(57.9 \%)$ of the household heads had no formal education. This is in accordance with a priori expectations that the level of illiteracy is high among rural dwellers (World Bank, 2008) and is expected to affect effective credit processing and usage. While more than four-fifths $(89.6 \%)$ of the respondents were married, occupational status of respondents showed that a major proportion were primarily engaged in farming. This implies that, for many households in rural Nigeria, agriculture remains the primary source of livelihood. The distribution of households by method of land acquisition revealed that a larger proportion $(78.6 \%)$ of the respondents acquired land by inheritance while the mean farm size stood at less than 1 hectare (0.6). This low hectarage can be attributed to the fragmentation of landholdings (mostly due to inheritance), as well as lack of access to modern farming inputs to cultivate large expanses of land.

\subsection{Profile of Households by their Credit Status}

According to Diagne and Zeller (2001), a farm household has access to credit from a particular source if it is able and entitled to borrow from that source. In this study, for proper analysis, rural households' access to credit was categorized into four (4) groups: saving associations, cooperative societies, commercial/microfinance banks, and friends and relatives. Table 2 shows that about $85.5 \%$ of the respondents had no access to formal credit while 14.5 percent had access to formal 
Table 1: Summary of Socio-economic Characteristics of Respondents

\begin{tabular}{|c|c|c|}
\hline Variables & Frequency & Percentage \\
\hline \multicolumn{3}{|l|}{ Gender } \\
\hline Male & 600 & 91.6 \\
\hline Female & 55 & 8.4 \\
\hline \multicolumn{3}{|l|}{ Age (years) } \\
\hline$\leq 29$ & 28 & 4.3 \\
\hline $30-49$ & 151 & 23.1 \\
\hline $40-49$ & 194 & 29.6 \\
\hline $50-59$ & 134 & 20.5 \\
\hline$\geq 60$ & 148 & 22.6 \\
\hline Mean & 48.2 & \\
\hline Standard deviation & 13.1 & \\
\hline \multicolumn{3}{|l|}{ Min. 19} \\
\hline \multicolumn{3}{|l|}{ Max. 90} \\
\hline \multicolumn{3}{|l|}{ Household size } \\
\hline $1-5$ & 214 & 32.6 \\
\hline $6-10$ & 318 & 48.6 \\
\hline $11-15$ & 114 & 17.4 \\
\hline$>15$ & 9 & 1.4 \\
\hline Mean & 7.3 & \\
\hline \multicolumn{3}{|l|}{ Standard deviation } \\
\hline \multicolumn{3}{|l|}{ Min. 1.0} \\
\hline \multicolumn{3}{|l|}{ Max. 24} \\
\hline \multicolumn{3}{|l|}{ Level of education } \\
\hline No formal education & 379 & 57.9 \\
\hline Primary & 164 & 25.0 \\
\hline Secondary & 94 & 14.4 \\
\hline Tertiary & 18 & 2.8 \\
\hline \multicolumn{3}{|l|}{ Marital status } \\
\hline Single & 7 & 1.1 \\
\hline Married & 587 & 89.6 \\
\hline Widowed & 52 & 7.9 \\
\hline Separated/Divorced & 9 & 1.3 \\
\hline \multicolumn{3}{|l|}{ Major occupation } \\
\hline Farming & 527 & 80.5 \\
\hline Non-farming & 128 & 19.5 \\
\hline \multicolumn{3}{|l|}{ Method of land acquisition } \\
\hline \multicolumn{3}{|l|}{ Inheritance } \\
\hline Purchase & 515 & 78.6 \\
\hline Rent or lease & 28 & 4.3 \\
\hline Used free of charge (Gift) & 27 & 4.1 \\
\hline Farm size (ha) & 85 & 13.0 \\
\hline \multicolumn{3}{|l|}{$<1$} \\
\hline $1-5$ & 447 & 68.2 \\
\hline$>5$ & 192 & 29.3 \\
\hline Mean $=16$ & 16 & 2.4 \\
\hline Standard deviation $=0.6$ & 0.6 & \\
\hline Min. $=0.2$ & 1.0 & \\
\hline Max. $=11.3$ & & \\
\hline
\end{tabular}

For each variable, frequency sums up to 655 and percentage to 100. Source: Author's Compilation from General Household Survey, 2012. 
credit. This implies that majority of the households still have limited access to bank services in the rural areas and were not able to access credit from this source. This result agrees with the findings of Ayegba and Ikani (2013) that commercial banks; and most microfinance banks with rural dwelling mandates are not found in the rural areas, instead they are found in the cities servicing urban dwellers against their statutory mandate. Also, it is evident from the study that dependence on cooperative societies by the respondents is very low as 4.3 percent of respondents were members of cooperative societies and 29.9 percent of the respondents had access to loan from one or two saving associations. On the other hand, none of the respondents signified having access to credit from friends and relatives.

According to Boucher et al. (2009) and Ayalew et al. (2014), this study follows the direct elicitation approach to categorize households into their credit constraint status. Households that were turned down for one reason or the other on request for credit (or loan) were classified as being credit constrained while households that showed no interest in credit, that is, did not want to borrow because their credit demand had been met were classified as being credit unconstrained. Results in table 2 also shows that almost two-fifths $(36.0 \%)$ of the households were credit constrained while the remaining $64.0 \%$ (a little more than three-fifths), were unconstrained. This is contrary to the findings of Omonona, Lawal and Oyinlana (2010) and Obisesan (2013) in their studies on credit constraints and accessibility respectively among farming households in Nigeria, in which credit-constrained households were in the majority, but agrees with the findings of Feder et al. (1990) and Fengxia et al. (2010) in their studies on the relationship between credit and productivity in agriculture and among rural households respectively, in which the proportion of credit-constrained households in the sample data was lower compared to those unconstrained.

Table 2: Rural Households' Credit Access and Status

\begin{tabular}{lcc}
\hline Variables & Frequency & Percent \\
\hline Commercial/Microfinance Banks & & \\
\hline Yes & 95 & 14.5 \\
No & 560 & 85.5 \\
Member of Cooperative Society & & \\
Yes & 28 & 4.3 \\
No & 627 & 95.7 \\
Saving Associations & & \\
Yes & 196 & 29.9 \\
No & 459 & 70.1 \\
Credit Status & & \\
Constrained & 236 & 36.0 \\
Unconstrained & 419 & 64.0
\end{tabular}

For each variable, frequency sums up to 655 and percentage to 100. Source: Author's Compilation from General Household Survey, 2012 


\subsection{Factors Influencing the Probability of Being Credit Constrained}

The criterion model shows the estimated coefficients from a probit estimate of the probability that a farm household is credit constrained, as presented in Table 3. The result shows that primary education reduced the probability of household being credit constrained, while secondary and tertiary education had no significant effects on the probability of being credit constrained. This suggests that, higher level of education does not primarily influence farming household credit status in the study area. This could be partially explained by the fact that higher level of education is not paramount to securing credit from financial institutions in the study area. Also, it fits with the intuition that household heads with higher level of education are more likely to rely on wage from non-farm labour more and rely less on obtaining credit. This result is contrary to empirical evidences. For instance, Ayalew et al. (2014) revealed that increase in the household head's year of schooling reduced the incidence of all types of credit constraints. However, for their study in Rwanda, they focused on the semi-formal sector (cooperatives, input suppliers, micro-finance institutions, and NGOs) as the relevant source of credit supply.

The positive and significant coefficient of household size of respondents implies that rural households with more household members have a higher probability of being credit constrained. This may be attributed to the high credit demand by these families to meet consumption requirements and to cultivate larger farmland for the sustenance of their families. This result conforms to other studies that credit beneficiaries with large household size were more credit constrained (Oyedele, Akintola, Rahji \& Omonona, 2009; Kuwornu, Ohene-Ntow \& AsumingBrempong, 2012).

Household assets endowment was statistically significant with a negative impact on credit constrained status. That is, the probability of being credit constrained reduces with an increase in the value of household assets. This could be attributed to the fact that assets can be used as collateral to secure loan or could also imply that households with assets have no need for credit. This result is in dissonance with the findings of Fengxia et al. (2010) but agrees with the findings of Ayalew et al. (2014), that wealthier households have own sufficient resources or face less difficulty in securing loans if in need of such. On the other hand, and contrary to a priori expectations, households with higher crop sale value have a higher probability of being credit constrained. This could be the case, if such households divert the proceeds of sales to other irrelevant uses or enticed by the crop sales value, decide to expand production beyond their capacity.

The location of households with respect to distance to market was significant. In other words, proximity to the market reduced the likelihood of a household being credit constrained. This could be an indication that households close to the market are able to make more sales and as a result are better off in terms of reduced transportation costs and post-harvest losses. Therefore, they do not need to rely or seek for credit. Also, the ease of access to credit through the siting of financial institutions in or close to the market, as is common in the rural areas, could be a key factor which would need to be further investigated. 
Table 3: Determinants of Credit Constraints and their Effect on Productivity

\begin{tabular}{|c|c|c|c|c|c|c|c|c|c|}
\hline \multirow[t]{3}{*}{ Variable } & \multicolumn{3}{|c|}{ Criteria Equation (Credit Constraint) } & \multicolumn{6}{|c|}{ Productivity Equation } \\
\hline & \multirow[b]{2}{*}{ Coef. } & \multirow[b]{2}{*}{ Std. Error } & \multirow[b]{2}{*}{ P-value } & \multicolumn{3}{|c|}{ Credit Constrained } & \multicolumn{3}{|c|}{ Credit Unconstrained } \\
\hline & & & & Coef. & Std. Error & P-value & Coef. & Std. Error & P-value \\
\hline Age & -0.020 & 0.025 & 0.440 & -0.064 & 0.043 & 0.140 & 0.005 & 0.038 & 0.904 \\
\hline $\mathrm{Age}^{2}$ & 0.522 & 0.607 & 0.390 & 1.561 & 1.055 & 0.139 & 0.006 & 0.914 & 0.995 \\
\hline Gender & 0.088 & 0.321 & 0.785 & $0.327 * *$ & 0.132 & 0.013 & $0.325 * *$ & 0.144 & 0.022 \\
\hline Hhsize & $0.059 * * *$ & 0.018 & 0.001 & -0.003 & 0.028 & 0.923 & 0.013 & 0.028 & 0.640 \\
\hline Edu pri & $-0.168 * *$ & 0.066 & 0.011 & -0.043 & 0.224 & 0.847 & -0.109 & 0.204 & 0.591 \\
\hline Edu-sec & 0.061 & 0.162 & 0.704 & 0.095 & 0.257 & 0.711 & $0.253 * *$ & 0.128 & 0.048 \\
\hline Edu tert & 0.144 & 0.293 & 0.624 & -0.419 & 0.448 & 0.350 & $0.480 * *$ & 0.274 & 0.080 \\
\hline Prioccup & 0.143 & 0.138 & \begin{tabular}{|l|}
0.297 \\
\end{tabular} & 0.150 & 0.213 & 0.479 & 0.167 & 0.211 & 0.429 \\
\hline Farm size & -0.002 & 0.047 & 0.964 & 0.048 & 0.074 & 0.519 & $-0.318 * * *$ & 0.066 & 0.000 \\
\hline Hhasset & $-0.154 * * *$ & 0.048 & 0.001 & $-0.245 * * *$ & 0.080 & 0.002 & $-0.264 * * *$ & 0.073 & 0.000 \\
\hline Household savin & 0.111 & 0.807 & 0.170 & & & & & & \\
\hline EntRev & -0.059 & 0.047 & 0.234 & & & & & & \\
\hline Output value & $0.337 * * *$ & 0.044 & 0.000 & & & & & & \\
\hline Purchase & -0.355 & 0.287 & 0.216 & -0.259 & 0.538 & 0.630 & -0.202 & 0.390 & 0.604 \\
\hline Inheritance & 0.068 & 0.135 & 0.613 & $0.405 *$ & 0.220 & 0.065 & 0.264 & 0.210 & 0.209 \\
\hline Mixedcrop & $-0.598 * *$ & 0.244 & 0.014 & -0.060 & 0.444 & 0.892 & 0.319 & 0.334 & 0.339 \\
\hline Monocrop & $0.726 * * *$ & 0.257 & 0.005 & 0.369 & 0.460 & 0.422 & $0.735 * *$ & 0.363 & 0.043 \\
\hline Labour cost & -0.026 & 0.053 & 0.623 & $-0.278 * * *$ & 0.087 & 0.001 & $0.367 * * *$ & 0.076 & 0.000 \\
\hline Distmarkt & $0.192 * *$ & \begin{tabular}{|l|}
0.081 \\
\end{tabular} & 0.018 & $0.435 * * *$ & 0.141 & 0.002 & 0.105 & 0.120 & 0.382 \\
\hline Distroad & -0.008 & 0.033 & 0.811 & $0.115^{* *}$ & 0.053 & 0.030 & -0.004 & 0.051 & 0.936 \\
\hline HerbUse & & & & $0.330^{*}$ & 0.185 & 0.074 & $0.697 * * *$ & 0.194 & 0.000 \\
\hline PestcdUse & & & & -0.357 & 0.220 & 0.105 & -0.196 & 0.202 & 0.333 \\
\hline FertUse & & & 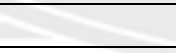 & $0.353^{*}$ & 0.184 & 0.055 & $0.541 * * *$ & 0.173 & 0.002 \\
\hline Phone & & & & 0.119 & 0.245 & 0.629 & $-0.403^{*}$ & 0.233 & 0.083 \\
\hline Radio & & & & 0.120 & 0.290 & 0.679 & $0.482 *$ & 0.273 & 0.078 \\
\hline IrrigUse & & 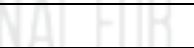 & $\sqrt{15}$ & -0.233 & 0.308 & 0.449 & $0.290 *$ & 0.163 & 0.073 \\
\hline EquipUse & & & & -0.039 & 0.190 & 0.838 & $0.565 * * *$ & 0.205 & 0.000 \\
\hline $\begin{array}{l}\text { sigma_1 } \\
\text { sigma_2 } \\
\text { rho_1 } \\
\text { rho_2 }\end{array}$ & & & & $\begin{array}{l}1.559 * * * \\
0.719 * * *\end{array}$ & $\begin{array}{l}0.098 \\
0.069\end{array}$ & & $\begin{array}{l}1.568 * * * \\
0.327\end{array}$ & $\begin{array}{l}0.088 \\
0.908 \\
\end{array}$ & \\
\hline
\end{tabular}


In addition, the two major cropping systems practiced by the households were significant. Specifically, mixed cropping system was found to decrease the probability of a household being credit constrained while households that practiced mono-cropping were more likely to be credit constrained. This could be because households who practice the mixed cropping system are able to take advantage of making higher sales with respect to at least two different crops which mature at different seasons. They are able to smooth consumption all year round and thus may not need to rely or seek for credit, while households that are engaged in monocropping are only able to make sales only when their crop is in season and may need to rely on credit.

\subsection{The Effect of Credit Constrained Condition on Productivity of Rural Households}

To achieve this, an endogenous switching regression model was estimated for credit constrained and unconstrained households' respectively. The full information maximum likelihood estimation of the model is shown in Table 3. The results are consistent with earlier findings both in terms of the estimation strategy and the ways through which credit constraints affect productivity. To ensure the robustness of the results, households were categorized as credit constrained if they have no option to borrow or were turned down in both informal and formal credit sectors.

In the model result, rho_l and rho_2 depict the correlation between the criterion equation and the production equation for the credit constrained and unconstrained households, respectively. The correlation coefficients rho_l (0.719) and rho_2 (0.327) are both positive but significant only for rho_l. Since rho_l is positive and significantly different from zero, the model indicates that households that were credit constrained had lower productivity than a random household from the sample would have had, and those who were not credit constrained had no better nor worse productivity than a random household. The likelihood-ratio test for joint independence of the three equations reported in the last line of the output $\left(\mathrm{chi}^{2}=60.05\right)$ showed that these three models are not jointly independent and should not be estimated separately.

The estimates from the productivity function showed that for credit constrained (0.327) and unconstrained households $(0.325)$, male headed households had a higher productivity irrespective of whether the household was credit constrained or not. The level of education however, had no significant effect on productivity if the household was credit constrained. This implies that, for education to improve productivity, the problem of rural credit constraints must be solved. This result is similar to that of Feder et al. (1990) and Fengxia et al. (2010). Contrarily, the level of education improved productivity if the household was credit unconstrained. Also, household heads with tertiary education had higher productivity compared to those with just secondary education.

Farm size was significant with a negative effect on crop productivity for households who were credit unconstrained. This implies that an increase in farm size will reduce productivity of credit unconstrained households. Although, this result is unexpected, it is consistent with evidence based on a study conducted by Byiringiro and Reardon (1996). It is also in line with the findings of Ayalew et al. (2014).

Value of household assets was found to be statistically significant in both the production and selection equation. An increase in household assets negatively affected productivity irrespective of whether the household was credit constrained or unconstrained, however, it affected the 
productivity of the unconstrained households more. This result is in line with the findings of Fengxia et al. (2010) in which farmers had less motivation to farm having obtained highly valued assets. Similarly, according to the findings of Winters et al. (2006), increased household asset value incentivized such households to participate more in non-farm businesses than agriculture.

On the other hand, the cost of hired labour used on the farm for planting, affected productivity negatively for households who were credit constrained. This suggests that under credit constrained condition, labour may be underutilized because households are unable to gather enough resources to hire labour up to the optimum. Thus, constrained households will find it difficult to increase their productivity through participation in the labour market as they lack the necessary resource (capital) to do so. However, for households who were credit unconstrained, increase in cost of hired labour increased productivity. This could be linked to the fact that higher cost of labor (wages) imply higher skill levels which increases productivity when these higher skilled workers are hired in unconstrained household farms.

Being engaged in mono cropping system of farming did not significantly affect the productivity of credit constrained households but increased the productivity for unconstrained ones, as it affords them the opportunity to utilize the same farm inputs, machinery and farming method on their entire farm, giving them a larger yield at a significantly lower cost. In contrast to that, acquisition of farmland by inheritance did not affect productivity for households who were credit unconstrained but significantly increased the productivity for credit constrained ones. This can be attributed to the fact that inheritance, a key means of acquiring asset, incentivizes and enhances the farmer's ability to invest, owing to a higher likelihood of access to institutional credit. Further, estimates from the productivity function showed that the use of herbicide and fertilizer increased productivity whether household was credit constrained or not. However, with respect to the use of herbicide, credit unconstrained households had higher productivity compared to those constrained.

Household heads access to agricultural information on phone and radio was used as a proxy to capture access to information. For the credit constrained household, there was no statistical effect for the use of these two devices by the household head. However, the result showed that the use of phone reduced productivity while that of radio increased productivity for unconstrained households. This indicates that the use of radio to access information on crop production was important for improving productivity. Although, the negative impact of the use of mobile phone on productivity, could not be ascertained and calls for further investigation.

The more the distance of homestead to the nearest market and the nearest major road respectively, the higher the productivity, if the household was credit constrained. This result is unexpected because farmers' decisions on the level and composition of production inputs to use are not causally linked to these factors. For instance, Foltz (2004) emphasized that the distance between household's farmland and the nearest market affected its profitability and not productivity. However, distance to both locations in this study, had no significant effect on the productivity of credit unconstrained households.

The use of farm machinery and irrigation significantly improved productivity if the household was credit unconstrained but had no significant effects for credit constrained households. The result 
with respect to use of farm machinery could be attributed to the fact that only a few (about $10 \%$ ) of the credit constrained households had used any form of equipment on their farm.

\section{CONCLUSIONS}

In this study, the use of an endogenous switching regression model accounted for both heterogeneity and sample selection issues. Results revealed that being credit constrained had significant effects on productivity although factors had different marginal contributions to productivity for credit constrained and unconstrained households. Specifically, households who were credit constrained had lower productivity than a random individual from the sample while those who were credit unconstrained had no worse productivity than a random individual from the sample would have had. Consequently, this implies that inputs required for production cannot be fully employed under credit constrained condition.

Thus, the significant and negative consequences of inadequate access to credit on aggregate and household-level outcomes, including technology adoption and overall agricultural productivity imply that efforts should be made to formulate rural credit policies that provide a reasonable amount of credit to farming households for securing required farm inputs. Also, credit facilities should be provided at no collateral, very low interest rates, and with simplification of procedures in obtaining credits. In other words, there should be institutional innovations to the problem of credit access by rural households who do not have collateral. This will encourage farmers to access credit through banks and enhance timely disbursement of loans to rural households. Also, these households could be organized into credit groups for ease of administration of loans and accountability as implemented in the rural areas of some developing and developed economies.

\section{REFERENCES}

Abu, G. A., Odoemenem, I. U., \& Ocholi, A. (2011). Determining optimum farm credit need of small scale farmers in Benue State. Journal of Economics and International Finance, 3 (10), 564-570.

Alene, A., \& Manyong, V. (2007). The effects of education on agricultural productivity under traditional and improved technology in northern Nigeria: An endogenous switching regression analysis. Empirical Economics, 32 (5), 141 - 159.

Awotide, B.A., Abdoulaye, T., Alene, A., \& Manyong, V. M. (2015). Impact of access to credit on agricultural productivity: Evidence from smallholder cassava farmers in Nigeria. Proceedings of the $29^{\text {th }}$ Conference of the International Association of Agricultural Economists. Milan, Italy.

Ayalew, D. A., Klaus, D., \& Marguerite, D. (2014). Credit constraints and agricultural productivity: Evidence from Rwanda. Policy Research Working Paper 6769, Development Research Group, The World Bank. Washington D.C.

Ayegba, O., \& Ikani, D. I. (2013). An impact assessment of agricultural credit on rural farmers in Nigeria, Research Journal of Finance and Accounting, 4, 25 - 35.

Boucher, S. R., Guirkinger, C., \& Trivelli, C. (2009). Direct elicitation of credit constraints: Conceptual and practical issues with an application to Peruvian agriculture. Economic Development and Cultural Change, 57 (4), 609 - 640.

Brauw, A. (2014). Migration, youth, and agricultural productivity in Ethiopia: Evidence from rural Ethiopia. IFPRI Discussion Paper 01594. 
Byiringiro, F., \& Reardon, T. (1996). Farm productivity in Rwanda: Effects of farm size, erosion, and soil conservation investments. Agricultural Economics, 15 (2), 127 - 136.

Carter, M., \& Olinto, P. (2003). Getting institutions right for whom? Credit constraints and impact of property rights on the quantity and composition of investment. American Journal of Agricultural Economics, 85 (1), 173 - 186.

Dercon, S., \& Christiaensen, L. (2011). Consumption risk, technology adoption and poverty traps: Evidence from Ethiopia. Journal of Development Economics, 96 (2), 159 - 173.

Diagne, A., \& Zeller, M. (2001). Access to credit and its impact on welfare in Malawi," IFPRI Research Report, No. 116. Retrieved from http://www.ifpri.org/pubs/abstract/116/rr116.pdf.

Ekpebu, I. (2006). Review of the Agricultural Sector in Nigeria (1960 - 1989). African Journal of Economy and Society, 7, 76 - 85.

Feder, G., Lau, L., Lin, J., \& Luo, X. (1990). The relationship between credit and productivity in Chinese agriculture: A microeconomic model of disequilibrium. American Journal of Agricultural Economics, 72 (5), 1151 - 1157.

Fengxia, D., Jing, L., \& Allen, M. F. (2010). Effects of credit constraints on productivity and rural household income in China. American Journal of Agricultural Economics, 90 (2), $409-423$.

Foltz, J. D. (2004). Credit market access and profitability in Tunisian agriculture. Agricultural Economics, 30 (3), 229 - 240.

Freeman, H., Ehui,S., \& Jabbar, M. (1998). Credit constraint and smallholder dairy production in the East African highlands: Application of a switching regression model. American Journal of Agricultural Economics, 19, 33 - 44.

Greene, W. H. (2008). Econometric Analysis ( $7^{\text {th }}$ ed.). New York, USA. University Prentice Hall New York.

Guirkinger, C., \& Boucher, S. R. (2005). Credit constraint and productivity in Peruvian Agriculture. Agricultural Economics, 39(3), 295 - 308.

Kuwornu, K. M.,Ohene-Ntow, I. D., \& Asuming-Brempong, S. (2012). Agricultural credit allocation and constraint analyses of selected maize farmers in Ghana. British Journal of Economics, Management and Trade, 2 (4), 353 - 374.

Lokshin, M., \& Sajaia, Z. (2004). Maximum likelihood estimation of endogenous switching regression models. The Stata Journal, 4 (3), 282 - 289.

Maddala, G. (1983). Limited dependent and qualitative variables in econometrics. Cambridge, England: Cambridge University Press England.

Obisesan, A. A. (2013). Credit accessibility and poverty among smallholder cassava farming households in southwest Nigeria. Greener Journal of Agricultural Sciences, 3 (2), 120 127.

Oboh, V. U. (2011). Determinants of formal agricultural credit allocation to the farm sector by arable crop farmers in Benue State, Nigeria. African Journal of Agricultural Research, 6, $181-185$.

Oladeebo, J. O., \& Oladeebo, O. E. (2008). Determinants of loan repayment among smallholder farmers in Ogbomosho agricultural zone of Oyo State, Nigeria. Journal of Social Sciences, 17 (2), 59 -62.

Olagunju, F. I., \& Adeyemo, R. (2008). Evaluation of the operational performance of the 
Nigerian agricultural credit cooperative and rural development bank (NACRDB) in southwestern Nigeria. International Journal of Agricultural Economics and Rural Development, 1 (1), 53-67.

Olajide, B. R., \& Aderolu, M. A. (2017). Effects of trust fund model credit intervention on welfare of farmers' households in Oyo State. Agrosearch, 17 (2), 38- 50.

Ololade, R. A., \& Olagunju, F. I. (2013). Determinants of access to credit among rural farmers in Oyo State, Nigeria. Global Journal of Science Frontier Research Agriculture and Veterinary Sciences, 13 (2), 17-22.

Omonona, B. T., Lawal, J. O., \& Oyinlana, A.O. (2010). Determinants of credit constraint conditions and production efficiency among farming households in southwestern Nigeria. The Social Sciences, 5 (4), $326-331$.

Oyedele, G. A., Akintola, J.O., Rahji, M. A.Y., \& Omonona, B. T. (2009). Credit constrained condition of farm households and profitability of agricultural production in Nigerian Agriculture. Journal of Agricultural and Food Sciences, 4, 192 - 201.

Petrick, M. (2005). Empirical measurement of credit rationing in agriculture: A methodological survey. Agricultural Economics, 33 (1), 191 - 203.

Phillip, D. E., Nkonya, J., P. \& Oni, O. A. (2009). Constraints to increasing agricultural productivity in Nigeria. Nigeria Strategy Support Program (NSSP) Background paper No. NSSP006.

Platteau, J. P. (2008). The food crisis in Africa and South America: A comparative structural analysis," In J. Dreze, A. Sen \& A. Hussain (Eds.), The political economy of hunger: selected essays. WIDER studies in development economics. Oxford, England: Oxford University Press England.

Udoh, E. J. (2005). Demand and control of credit from informal sources by rice producing females of Akwa Ibom State, Nigeria. Journal of Agriculture and Social Sciences, 1, 152 -155 .

Ugbajah, M. O. (2011). Gender analysis of the structure and effects of access to financial services among rural farmers in Anambra State, Nigeria. Journal of Agricultural Science, 2 (2), 107-111.

Winters, P., Davis, B., Carletto, G., Covarrubia, K., Quiñones, E.J., Zezza, A., ... Stamoulis, K. (2009). Assets, activities and rural income generation: evidence from a multi-country analysis. World Development, 37 (9), 1435-1452.

Wooldridge, J. (2010). Solutions manual and supplementary materials for econometric analysis of cross-section and panel data. Cambridge, England: The MIT Press England.

World Bank (2008). Agriculture for development. World development report 2008: Washington DC: The World Bank. Retrieved from http://documents.worldbank.org/. 